\title{
Moving Towards Optimized Noncommunicable Disease Management in the ASEAN Region: Recommendations from a Review and Multidisciplinary Expert Panel
}

This article was published in the following Dove Press journal:

Risk Management and Healthcare Policy

\begin{abstract}
Nina T Castillo-Carandang, (iD) Robert D Buenaventura, ${ }^{2}$ YookChin Chia, (iD) ${ }^{3}$ Dung Do Van, (iD) 4 Cheng Lee, (iD) ${ }^{5}$ Ngoc Long Duong, (iD) ${ }^{6}$ Chee $\mathrm{H} \mathrm{Ng}$, iD ${ }^{7}$ Yolanda R Robles, ${ }^{8}$ Anwar Santoso, (iD) ${ }^{9}$ Helen S Sigua, (iD) 10 Apichard Sukonthasarn, (iD) " Roger Tan, 12 Eka Viora, ${ }^{13}$ Hazli Zakaria, ${ }^{14}$

Grace E Brizuela, (iD ${ }^{15}$

Priyan Ratnasingham, ${ }^{16}$

Mathew Thomas, (iD) ${ }^{17}$ Anurita Majumdar ${ }^{16}$

'Department of Clinical Epidemiology, College of Medicine, University of the Philippines Manila, Manila, Philippines; and Institute of Clinical Epidemiology, National Institutes of Health, University of the Philippines Manila, Manila, Philippines; ${ }^{2}$ Department of Psychiatry, Manila Theological College - College of Medicine, Manila, Philippines; ${ }^{3}$ Department of Medical Sciences, School of Healthcare and Medical Sciences, Sunway University, Bandar Sunway, Selangor, Malaysia; ${ }^{4}$ The University of Medicine and Pharmacy at Ho Chi Minh City, Ho Chi Minh City, Vietnam; ${ }^{5}$ National Addictions Management Service, Institute of Mental Health, Singapore; ${ }^{6}$ Department of Research, Education and Technology, Vietnam National Heart Institute, Hanoi, Vietnam; ${ }^{7}$ Department of Psychiatry, The Melbourne Clinic and St Vincent's Hospital, University of Melbourne, Richmond, VIC, Australia; ${ }^{8}$ College of Pharmacy, University of the Philippines Manila, Manila, Philippines; 'Department of Cardiology, Vascular Medicine, National Cardiovascula Centre - Harapan Kita Hospital, Universitas Indonesia Jakarta, Indonesia; ${ }^{10}$ University of the Philippines Open University, Laguna, Philippines; "'Department of Internal Medicine, Faculty of Medicine, Chiang Mai University, Chiang Mai, Thailand; ${ }^{12}$ Roger Kidney Clinic, Gleneagles Hospital, Singapore; ${ }^{13}$ Indonesia Psychiatrist Association, Jakarta, Indonesia; ${ }^{14}$ Department of Psychiatry, Faculty of Medicine, Universiti Kebangsaan Malaysia Medical Centre, Kuala Lumpur, Malaysia; ${ }^{15}$ Research, Development and Medical, Pfizer Upjohn, Manila, Philippines; ${ }^{16}$ Research, Development and Medical, Pfizer Upjohn, Singapore:

${ }^{17}$ Corporate Affairs, Pfizer Upjohn, Singapore
\end{abstract}

Correspondence: Nina T Castillo-

Carandang

Tel +632-8-5254098

Email ntcastillocarandang@up.edu.ph
Introduction: Noncommunicable diseases (NCDs) are the leading cause of morbidity and mortality in the Association of Southeast Asian Nations (ASEAN) member states. Progress has been slow despite the World Health Organization action plan for the prevention and control of NCDs in the region. This paper presents recommendations focused on practical strategies for optimizing NCD management in the ASEAN region.

Methods: A multidisciplinary group of experts from six ASEAN member states convened for two face-to-face meetings to discuss barriers and possible recommendations for optimizing NCD management, focused on cardiovascular diseases and mental disorders, in the region. Multiple approaches, ie, analysis of insights from the meetings and a review of existing literature on NCD programs in the ASEAN region were followed. The proposed recommendations were also based on selected successful interventions in ASEAN member states, thus providing actionable strategies.

Results: The gaps identified in NCD management for cardiovascular diseases and mental disorders in the ASEAN region were classified into gaps relating to policies and to clinical and public health practice. The proposed solutions addressing policy gaps include fostering multisectoral public-private partnerships, employing "whole-of-government" and "whole-ofsociety" approaches and promoting "health-in-all policies approach" to manage issues with financing, accessibility, efficiency and quality of health services. Whereas proposed solutions to bridge clinical and public health practice gaps entail strengthening primary care services, building the capacity of trained healthcare workers and employing collaborative care for holistic management of patients.

Conclusion: The scale of premature and preventable deaths from NCDs in the ASEAN region remains a serious public health concern and requires a "whole-of-system approach". The interventions proposed in this paper build on regional collaborations and knowledge sharing to help develop a concerted and targeted response to NCDs.

Keywords: cardiovascular disease, mental health, prevention strategies, public health

\section{Introduction}

In Southeast Asian region, noncommunicable diseases (NCDs) are the leading cause of mortality, accounting for an estimated $62 \%$ (8.5 million) of all deaths; approximately $50 \%$ of these deaths occur in people under 70 years of age. ${ }^{1}$ Four major NCDs, ie, cardiovascular diseases (CVDs), diabetes, cancers and chronic 
respiratory diseases contribute to more than $80 \%$ of NCDrelated premature deaths. Mental disorders are the fifth leading contributor of NCD burden and frequently cooccur with the four major NCDs. ${ }^{2}$ Overall, NCDs account for $44 \%$ of total disability-adjusted life years (DALYs) in Southeast Asian countries with mental disorders constituting the largest proportion (27\%) (Table 1). ${ }^{3,4}$

The Association of Southeast Asian Nations (ASEAN) is a regional organization comprised of 10 member countries from the Southeast Asian region (Brunei Darussalam, Cambodia, Indonesia, Lao PDR, Malaysia, Myanmar, Philippines, Singapore, Thailand, and Vietnam). The scale of premature and preventable deaths from NCDs in the ASEAN region remains a serious public health concern requiring a "whole-of-system approach"-warranting response not only from doctors and allied healthcare professionals, but also policy makers, educators, private sector and society at all stages along the continuum of care.

\section{Burden of NCDs}

Southeast Asian countries face a triple burden of diseasethe backlog of communicable diseases, maternal mortality, and undernutrition; the emerging challenges from NCDs; and the consequences of industrialization and globalization, eg, climate change. ${ }^{5}$ The triple burden of disease in the region is further compounded by a demographic transition into an ageing population. ${ }^{6}$ Urbanization and globalization in the Southeast Asian region have brought about a rapid change in lifestyle-related NCD risk factors including unhealthy diet and physical inactivity. ${ }^{6,7}$ The prevalence of the underlying risk factors of NCDs across all ASEAN member states is presented in Table $2{ }^{8}$ Among these shared and preventable risk factors, tobacco use is the leading cause of NCD-related deaths and its prevalence ranged from 15$39 \%$ in the ASEAN region in $2016 .^{8,9}$

The microeconomic burden from NCDs is exerted directly through loss of productivity encompassing the intangible cost of caregiver burden and indirectly through out-ofpocket expenditure on medical care. ${ }^{6}$ In Asia, the costs of managing NCDs burden governments and have disastrous consequences on patients and their families. ${ }^{10}$ At the macroeconomic level, the cost of inaction on NCDs in low- and middle-income countries (LMICs), is estimated at USD 7 trillion between 2011 and 2025. ${ }^{11,12}$ Between 2011 and 2030, mental disorders will cost USD 16 trillion in lost economic output globally - more than cancer, diabetes and respiratory diseases combined. ${ }^{12}$ The direct economic losses from CVD and diabetes combined in Myanmar, Indonesia, Philippines,
Thailand, and Vietnam were estimated at USD 7 billion between 2006 and 2015. ${ }^{6,13}$ In light of this epidemiologic and economic burden, the World Health Organization (WHO) has identified a number of policy actions, the most cost-effective interventions and other recommended services, collectively termed as "Best buys", to assist member states toward achieving reduction in premature mortality from NCDs. "14 "Best buys" are interventions that offer the optimum mix of policies and actions needed to address the problem of NCDs. The projected cost of implementing a full array of these "Best buys" across all LMICs is USD 170 billion; ${ }^{11,12}$ however, data on the effectiveness of these best buys in LMICs is limited. ${ }^{15}$

\section{Healthcare Systems in ASEAN Member States}

The vast economic and sociocultural heterogeneity within the ASEAN region leads to disparities between the national capacities for NCD control (Table 3). ${ }^{8,16-19}$ This, combined with diverse health systems and healthcare financing structures in individual ASEAN member states, (Figure 1) contributes to disparate universal health coverage (UHC) in the region. ${ }^{17,20}$ Malaysia, Singapore and Thailand provide health care coverage to all citizens with some form of government-subsidized health financing schemes. ${ }^{21}$ Indonesia achieved complete UHC in 2019, whereas the healthcare coverage in the Philippines (76\%), and Vietnam (82\%) remained suboptimal. ${ }^{21-23}$ Despite the diversity in healthcare systems, regional and international collaborations are essential to overcome healthcare challenges in Southeast Asian countries as witnessed by recent infectious disease epidemics in the region. $^{24}$ Similar collaborative strategies are needed to strengthen healthcare systems in the ASEAN region to deliver the NCD continuum-of-care and empower patients, families and communities. $^{25}$

Some studies have previously proposed strategies for NCD management in Southeast Asian countries. ${ }^{6,26,27}$ Lim et al reported 12 innovative solutions for NCD management from ASEAN region. ${ }^{26}$ Dans et al proposed strategies for NCD control in Southeast Asian countries based on global and regional action plans. ${ }^{6}$ Ezzati et al reported strategies for effective interventions for NCDs in LMICs. ${ }^{27}$ Despite these efforts, and a WHO action plan for prevention and control of NCDs in Southeast Asian region, progress has been slow in all ASEAN member states except Singapore. ${ }^{28}$ This underscores the need for a regional response built on existing alliances and knowledge sharing for a concerted action plan towards NCDs. 
Table I Burden of NCDs in Selected ASEAN Member States ${ }^{\mathrm{a}}$ in 2017

\begin{tabular}{|l|l|l|}
\hline & $\begin{array}{l}\text { Death } \\
\text { (n) }\end{array}$ & $\begin{array}{l}\text { Disability } \\
\text { (Years) }\end{array}$ \\
\hline Cardiovascular diseases & 4.2 million & 6.6 million \\
Chronic respiratory diseases & 1.5 million & 13.7 million \\
Cancer & 1.6 million & 0.9 million \\
Diabetes and chronic kidney disease & 0.8 million & 12 million \\
Mental disorders & 0.06 million $^{c}$ & 32 million \\
\hline
\end{tabular}

Notes: Data from Institute for Health Metrics and Evaluation, GBD Compare. ${ }^{2}$ Data are for the following selected ASEAN countries: Indonesia, Malaysia, Philippines, Singapore, Thailand, and Vietnam. ${ }^{b}$ Disability is measured as disabilityadjusted life years (DALYs). ${ }^{c}$ Death from mental disorders, suicide and self-harm (excluding mortality from comorbid NCDs in people with mental disorders).

Abbreviations: ASEAN, Association of Southeast Asian Nations; NCDs, noncommunicable diseases.

\section{Scope of the Study}

This paper presents recommendations from a multidisciplinary group of experts from six ASEAN member states for optimizing NCD management in the region. The recommendations focus on practical strategies for action supported by successful case studies from the region. This paper focuses on CVD and mental disorders, as they are the leading causes of NCD-related mortality and disability in the region, respectively. ${ }^{1,3}$

\section{Methods}

\section{Data Collection}

A multidisciplinary group $(\mathrm{n}=83)$ of healthcare professionals (HCPs) including a health social scientist from the ASEAN region met at a seminar workshop in August 2019 to discuss barriers and possible recommendations for optimizing NCD management in the region, focused on CVD and mental health disorders. The meeting aimed to highlight the rising NCD burden, share current best practices in NCD management, identify gaps to improve NCD outcomes and propose novel initiatives to address these gaps. The multidisciplinary participants comprised specialists (cardiologists, nephrologists, psychiatrists, and geriatric physicians), general practitioners (GPs), nurse specialists, pharmacists, nutritionists, epidemiologists, and public health advocates from six ASEAN member states: Indonesia (14), Malaysia (13), Philippines (13), Singapore (15), Thailand (13) and Vietnam (15). A subgroup of HCPs ( $\mathrm{n}=14)$; Indonesia (2), Malaysia (2), Philippines (4), Singapore (1), Thailand (2), Vietnam (2) and Australia (1) from the first meeting convened for a second face-to-face meeting in November 2019 to further refine the recommendations. Multiple approaches including an analysis of insights from the two meetings and a review of existing literature on NCD-related programs in the ASEAN region were followed in this study.

\section{Data Analysis and Data Validation}

Insights were gathered during the seminar-workshop meeting using Workmat ${ }^{\circledR}$ methodology - a poster-based exercise to maximize interaction between participants to reach conclusions on a specific topic. ${ }^{29}$ The insights were analyzed qualitatively using a thematic analysis approach to identify major themes relating to gaps in NCD management (Supplementary Figure 1). ${ }^{30}$ Next, the recommendations comprising recommended action(s), potential stakeholders

Table 2 Prevalence of Behavioral and Metabolic NCD Risk Factors in the ASEAN Member States

\begin{tabular}{|c|c|c|c|c|c|c|c|}
\hline & $\begin{array}{l}\text { Current } \\
\text { Tobacco } \\
\text { Smoking, } \\
\text { Aged } \geq 15 \\
\text { Years }\end{array}$ & $\begin{array}{l}\text { Insufficient } \\
\text { Physical } \\
\text { Activity, Aged } \\
\geq 18 \text { Years }\end{array}$ & $\begin{array}{l}\text { Mean Population Salt/ } \\
\text { Sodium Intake, Aged } \\
\geq 20 \text { Years (g/day) }\end{array}$ & $\begin{array}{l}\text { Total Alcohol/Capita } \\
\text { Consumption, Aged } \geq 15 \\
\text { Years (Liters of Pure } \\
\text { Alcohol) }\end{array}$ & $\begin{array}{l}\text { Raised Blood } \\
\text { Pressure, } \\
\text { Aged } \geq 18 \\
\text { Years }\end{array}$ & $\begin{array}{l}\text { Obesity } \\
\text { (Aged } \geq 18 \\
\text { Years, Aged } \\
10-19 \\
\text { Years) }\end{array}$ & $\begin{array}{l}\text { Raised Blood } \\
\text { Glucose, } \\
\text { Aged } \geq 18 \\
\text { Years }\end{array}$ \\
\hline $\begin{array}{l}\text { Brunei } \\
\text { Darussalam }\end{array}$ & $17 \%$ & $26 \%$ & 11 & 0 & $18 \%$ & $15 \%, 12 \%$ & $9 \%$ \\
\hline Cambodia & $15 \%$ & $10 \%$ & 11 & 7 & $23 \%$ & $4 \%, 3 \%$ & $6 \%$ \\
\hline Indonesia & $39 \%$ & $22 \%$ & 9 & 1 & $22 \%$ & $7 \%, 5 \%$ & $7 \%$ \\
\hline Lao PDR & $27 \%$ & $15 \%$ & 11 & 10 & $19 \%$ & $5 \%, 4 \%$ & $6 \%$ \\
\hline Malaysia & $22 \%$ & $38 \%$ & 9 & 1 & $21 \%$ & $15 \%, 11 \%$ & $10 \%$ \\
\hline Myanmar & $20 \%$ & $10 \%$ & 11 & 5 & $23 \%$ & $6 \%, 3 \%$ & $7 \%$ \\
\hline Philippines & $24 \%$ & $38 \%$ & 11 & 7 & $19 \%$ & $6 \%, 3 \%$ & $6 \%$ \\
\hline Singapore & $16 \%$ & $38 \%$ & 13 & 2 & $17 \%$ & $7 \%, 6 \%$ & $9 \%$ \\
\hline Thailand & $21 \%$ & $25 \%$ & 13 & 8 & $25 \%$ & $11 \%, 10 \%$ & $10 \%$ \\
\hline Vietnam & $23 \%$ & $25 \%$ & 12 & 8 & $22 \%$ & $2 \%, 2 \%$ & $5 \%$ \\
\hline
\end{tabular}

Note: Data from the World Health Organization. ${ }^{8}$

Abbreviations: ASEAN, Association of Southeast Asian Nations; BMI, body mass index; NCD, noncommunicable diseases. 


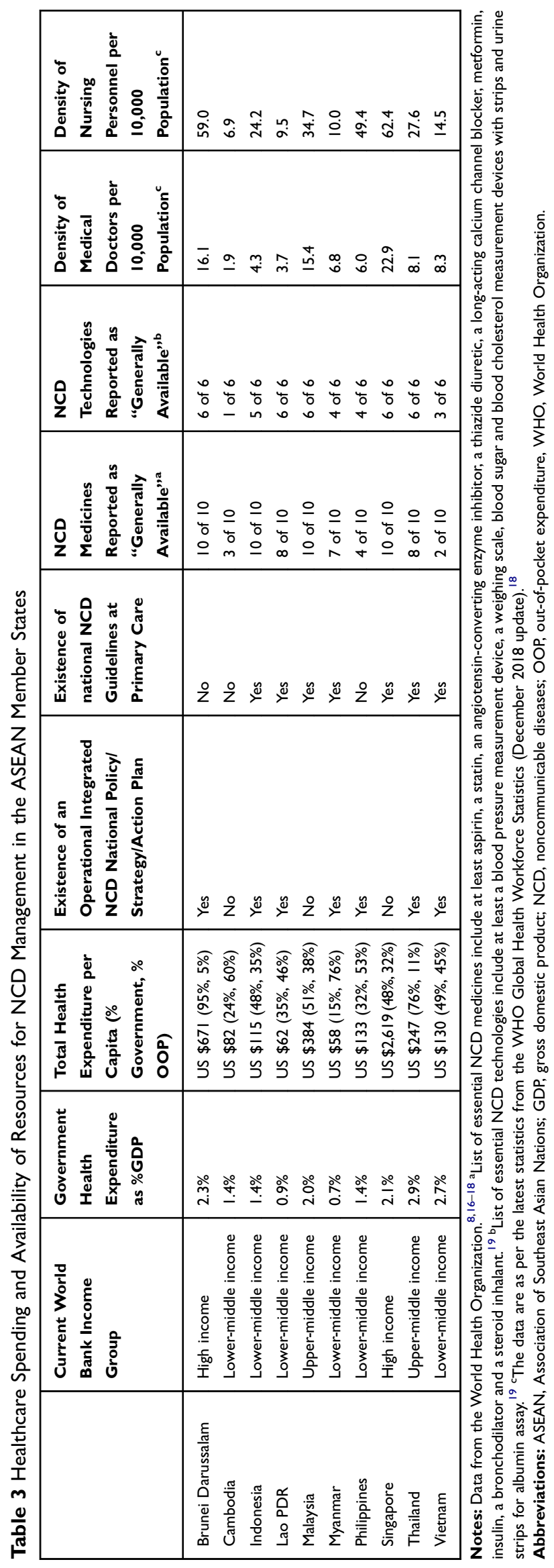

and performance indicators proposed during the workshops were compared and categorized under the appropriate theme. Further, case studies of NCD interventions implemented either at local or national level in the six ASEAN member states and shared at the seminar-workshop, at the subsequent face-to-face meeting, or during the development of this paper were organized under the appropriate theme and recommendation. The current status and influence of the case studies on policy, clinical practice and public health program were confirmed by contacting an appropriate country point-of-contact. Finally, the recommendations were individually ranked by each expert, who are authors in this paper, in terms of its priority for NCD control in the ASEAN region. Consensus on the recommendations and the case studies included in this paper was reached following debates and exchange of information by the experts during and following the two face-to-face meetings.

\section{Results}

Gaps identified in NCD management in ASEAN member states, in relation to CVD and mental health disorders, were classified under two main themes: one relating to policies and the other relating to clinical and public health practice. The proposed recommendations for addressing these gaps were arranged under the appropriate themes (Tables 4 and 5) and further supplemented with the relevant case studies from the region.

\section{Theme I: Addressing NCD Policy Gaps in the ASEAN Region \\ Implement National NCD Screening Programs by Providing Adequate Resources (Healthcare Facilities and Trained Health Workers) \\ Regional Context}

Metabolic risk factors such as raised blood pressure (BP), high body mass index (BMI) or waist-to-hip ratio, elevated blood sugar levels and abnormal serum lipid concentrations contribute largely to the global NCD burden. ${ }^{31-34}$ These risk factors have similar effects across Asian and other populations. ${ }^{35}$ To reduce morbidity and premature mortality from NCDs, all WHO member countries have adopted global targets for select NCD risk factors (tobacco and alcohol use, salt intake, obesity, and raised levels of $\mathrm{BP}$ and glucose). Achieving these targets is expected to delay more than 31 million deaths in LMICs from the four major NCDs between 2020 and 2025. ${ }^{36}$ 


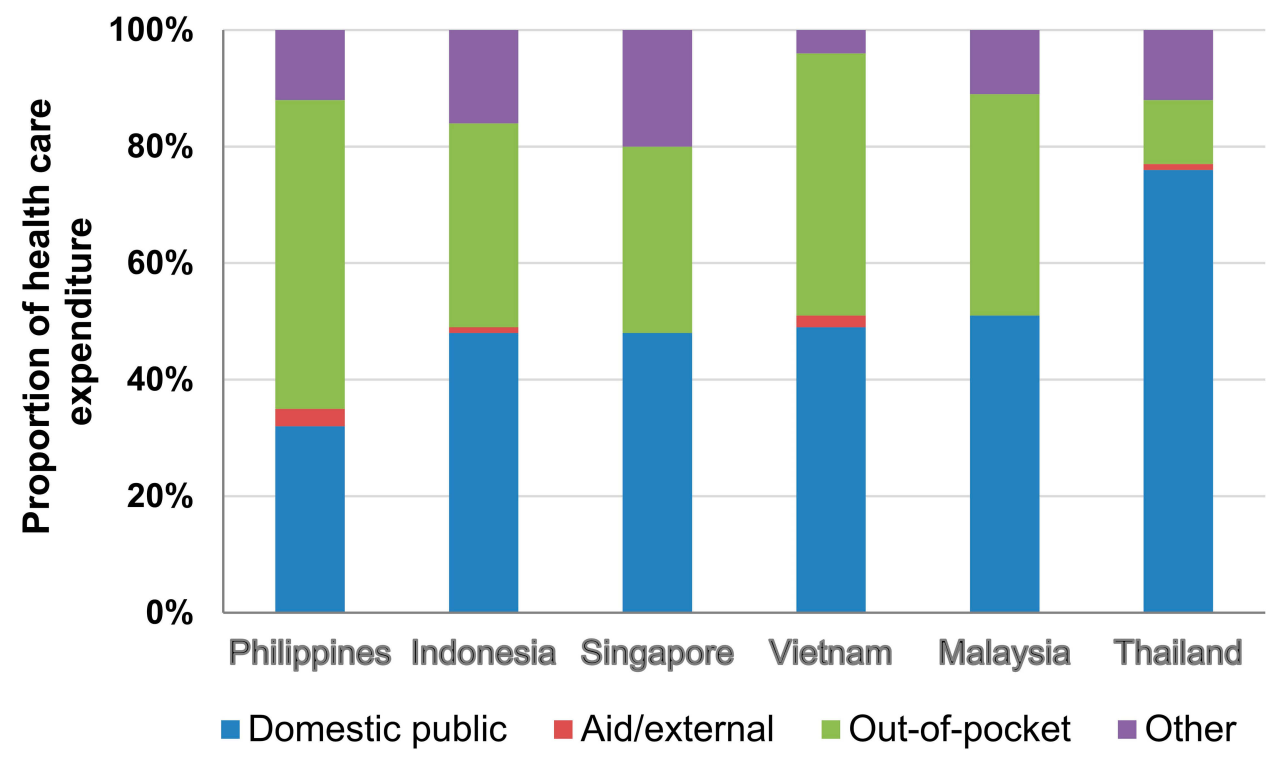

Figure I Structure of health expenditure in selected ASEAN member states in 2017

Note: Data from the World Health Organization. ${ }^{17}$

Abbreviation: ASEAN, Association of Southeast Asian Nations.

\section{Case Study}

In 2011, Malaysia had the highest prevalence of NCD risk factors (diabetes, 15\%; hypertension, 32\%; hypercholesterolemia, $35 \%$; obesity, $15 \%$ ) among the ASEAN member states. ${ }^{37}$ In 2013, the Ministry of Health in collaboration with other government agencies implemented Komuniti Sihat Perkasa Negara (KOSPEN), a grassroot-level community program, across Malaysia to increase the coverage of NCD risk factor interventions. ${ }^{37}$ Under KOSPEN, community volunteers ("health agents of change") were trained to drive health promoting activities, policy advocacy, NCD risk factor screening, clinic referrals and other health promoting intervention programs. KOSPEN also contributes to an enhanced primary healthcare project, which undertakes chronic disease screening at the community level, implementation of patient-centered care at health clinics and referral of at-risk patients. In 2019, there were 6018 KOSPEN localities and 36,000 trained volunteers, and over one million adults screened for NCD risk factors. ${ }^{37}$ Overall, KOSPEN has been implemented well and is perceived positively by all stakeholders. ${ }^{38}$ The majority of KOSPEN implementors and volunteers demonstrated a high level of knowledge about the core activities, awareness of their roles and responsibility and acceptance of the program. ${ }^{39}$ The program has a high level of awareness among the community with approximately $45 \%$ participating in the KOSPEN activities. $^{38}$

\section{Improve Access to NCD Medications Regional Context}

Availability of medicines is consistently lower in public sector facilities vs private sector and in LMICs vs higher-income countries. ${ }^{40}$ Despite limited efficacy data, high proportion of population in ASEAN member states use traditional, complementary, and alternative medicines for chronic conditions such as cancer and diabetes. ${ }^{41}$ Providing equitable access to quality NCD medications in developing countries needs a focus on supply chain efficiency, regulatory requirement harmonization and primary care. ${ }^{40}$ Improving delivery provisions and existing medication usage outweighs the benefits from developing new compounds toward improving access. ${ }^{42}$

\section{Case Study}

In the Philippines, there are around 12 million people with hypertension. ${ }^{43}$ The cost of medicines remains high in comparison by international standards and a large proportion of the direct medical costs for hypertension and CVD fall on the patient in the form of out-of-

pocket payments. ${ }^{44}$ Therefore, the Philippine government planned to subsidize outpatient pharmaceuticals for diseases including hypertension through PhilHealth. ${ }^{44}$ In 2016, the Philippines Department of Health launched the "Hypertension and Diabetes Club" program to provide free maintenance medicines for hypertension and diabetes to patients diagnosed using the Philippine Package of 
Table 4 Proposed Recommendations for Addressing Gaps in Policies for Optimizing NCD Management in the ASEAN Member States

\begin{tabular}{|c|c|c|c|}
\hline & Recommended Actions & Potential Stakeholders & Performance Indicators \\
\hline $\begin{array}{l}\text { I. Implement national NCD } \\
\text { screening programs by pro- } \\
\text { viding adequate resources } \\
\text { (healthcare facilities and } \\
\text { trained health workers) }\end{array}$ & $\begin{array}{l}\text { Conduct annual/biannual screening-a } \\
\text { minimum of BMI, BP, blood sugar, } \\
\text { blood lipid measurements as defined } \\
\text { by existing clinical practice guidelines } \\
\text { in the country } \\
\text { - Train community volunteers as auxili- } \\
\text { ary healthcare workers }\end{array}$ & $\begin{array}{l}\text { Government, healthcare volunteers, } \\
\text { nonprofit organizations, HCPs and } \\
\text { community }\end{array}$ & $\begin{array}{l}\text { - Proportion of eligible population } \\
\text { screened per year }\end{array}$ \\
\hline $\begin{array}{l}\text { 2. Improve access to NCD } \\
\text { medication }\end{array}$ & $\begin{array}{l}\text { - Regulate to ensure general availability } \\
\text { of NCD medicines and basic technol- } \\
\text { ogies at public and private primary } \\
\text { care centers through UHC or health } \\
\text { insurance } \\
\text { - Increase availability of cost-effective } \\
\text { NCD interventions and quality low- } \\
\text { cost generics in the basic primary } \\
\text { healthcare package } \\
\text { - Explore evidence-based and viable } \\
\text { health-financing mechanisms and inno- } \\
\text { vative economic tools }\end{array}$ & $\begin{array}{l}\text { Government, payers, pharmaceutical } \\
\text { organizations, pharmacies, technology } \\
\text { companies, HCPs and society }\end{array}$ & $\begin{array}{l}\text { - Access and availability of essential } \\
\text { NCD medications including qual- } \\
\text { ity low-cost generics and tech- } \\
\text { nologies in private and public } \\
\text { healthcare facilities } \\
\text { - Population covered by UHC or } \\
\text { other forms of health insurance }\end{array}$ \\
\hline $\begin{array}{l}\text { 3. Introduce health promotion } \\
\text { programs in schools, universi- } \\
\text { ties, workplaces and public/ } \\
\text { private spaces }\end{array}$ & $\begin{array}{l}\text { - Organize NCD risk factor awareness } \\
\text { programs } \\
\text { - Introduce school and work-based meal } \\
\text { programs with healthy and balanced } \\
\text { diet }\end{array}$ & $\begin{array}{l}\text { Government, education institutions, } \\
\text { nonprofit organizations, nutrition experts } \\
\text { and society }\end{array}$ & $\begin{array}{l}\text { - Incidence of diabetes, hyperten- } \\
\text { sion and obesity in the population }\end{array}$ \\
\hline $\begin{array}{l}\text { 4. Pass and implement legislation } \\
\text { to reduce NCD risk factors } \\
\text { (tobacco use, excessive alco- } \\
\text { hol use and salt intake) }\end{array}$ & $\begin{array}{l}\text { - Increase taxes on tobacco and alcohol } \\
\text { - Implement salt tax on food processing } \\
\text { industry } \\
\text { - Ban use of trans-fat in processed food }\end{array}$ & $\begin{array}{l}\text { Government, civil society, nonprofit } \\
\text { organizations, tobacco industry, food } \\
\text { industry, private sector and academia }\end{array}$ & $\begin{array}{l}\text { - Trend in number of smokers } \\
\text { - Trend in average alcohol } \\
\text { consumption } \\
\text { - Salt intake }<5 \mathrm{~g} / \text { day (measured by } \\
\text { dietary record or urinary sodium } \\
\text { excretion) in the adult population }\end{array}$ \\
\hline $\begin{array}{l}\text { 5. Provide an encouraging physi- } \\
\text { cal and social environment for } \\
\text { people to practice healthy } \\
\text { habits and incentivize healthy } \\
\text { lifestyle }\end{array}$ & $\begin{array}{l}\text { - Create smoke-free areas in cities } \\
\text { - Improve pedestrian and bicycle net- } \\
\text { work infrastructure across city } \\
\text { - Increase green, open and safe spaces in } \\
\text { cities } \\
\text { - Reduce air pollution } \\
\text { - Provide incentive-linked health insur- } \\
\text { ance schemes }\end{array}$ & $\begin{array}{l}\text { Government, healthcare organizations, } \\
\text { professional organizations, educational } \\
\text { systems, health insurance companies, } \\
\text { nonprofit organizations, media outlets, } \\
\text { technology companies, food industry, } \\
\text { health and fitness industry, transportation } \\
\text { sector, real estate companies and society }\end{array}$ & $\begin{array}{l}\text { - Percent of population with } \geq 2.5 \\
\text { hours of moderate aerobic physi- } \\
\text { cal activity per week } \\
\text { - Incidence of obesity in the } \\
\text { population }\end{array}$ \\
\hline $\begin{array}{l}\text { 6. Integrate mental health in the } \\
\text { management of chronic con- } \\
\text { ditions in primary care } \\
\text { settings }\end{array}$ & $\begin{array}{l}\text { - Integrate mental health care into } \\
\text { national health policy using simple, } \\
\text { cost-effective screening tools for } \\
\text { depression, anxiety or stress } \\
\text { - Prioritize screening of mental disor- } \\
\text { ders in NCD patients with poorly } \\
\text { controlled risk factors (such as high } \\
\text { blood sugar, BP and BMI) or with poor } \\
\text { adherence, with appropriate referral } \\
\text { for treatment in both primary and } \\
\text { specialist care services }\end{array}$ & $\begin{array}{l}\text { Government, professional organizations, } \\
\text { psychiatrists, healthcare volunteers, } \\
\text { psychiatrists, GPs, nurses and healthcare } \\
\text { workers }\end{array}$ & $\begin{array}{l}\text { - Percent of ASEAN countries with } \\
\text { an operational integrated national } \\
\text { health plan with mental health risk } \\
\text { assessment } \\
\text { - Percent of patients with uncon- } \\
\text { trolled chronic conditions } \\
\text { screened for mental disorders } \\
\text { - Number of people screened for } \\
\text { mental health problems at pri- } \\
\text { mary care facilities }\end{array}$ \\
\hline
\end{tabular}

Abbreviations: ASEAN, Association of Southeast Asian Nations; BMI, body mass index; BP, blood pressure; CVD, cardiovascular diseases; GPs, general physicians; HCPs, healthcare professionals; NCDs, noncommunicable diseases; UHC, universal health coverage 
Table 5 Proposed Recommendations for Addressing Gaps in Clinical and Public Health Practice for Optimizing NCD Management in the ASEAN Member States

\begin{tabular}{|c|c|c|c|}
\hline Recommendations & Recommended Actions & Potential Stakeholders & Performance Indicators \\
\hline $\begin{array}{l}\text { I. Set up local public and private } \\
\text { primary care networks }\end{array}$ & $\begin{array}{l}\text { - Set up primary care networks with } \\
\text { shared target goals, referral services and } \\
\text { treatment guidelines }\end{array}$ & $\begin{array}{l}\text { Government and private sector, } \\
\text { professional organizations and } \mathrm{HCPs}\end{array}$ & $\begin{array}{l}\text { - Number of operational pri- } \\
\text { mary care networks deployed } \\
\text { in the region }\end{array}$ \\
\hline $\begin{array}{l}\text { 2. Improve treatment adherence } \\
\text { using evidence-based and } \\
\text { innovative solutions }\end{array}$ & $\begin{array}{l}\text { Develop evidence-based digital platforms } \\
\text { to facilitate patient self-care, patient } \\
\text { communication and patient education } \\
\text { - Promote SDM through patient decision- } \\
\text { making tools and SDM training work- } \\
\text { shops for HCPs }\end{array}$ & $\begin{array}{l}\text { Professional organizations, HCPs, nurses, } \\
\text { pharmacists, technology companies, } \\
\text { pharmaceutical sector, individuals and } \\
\text { caregiver }\end{array}$ & $\begin{array}{l}\text { - Treatment adherence rate for } \\
\text { NCDs }\end{array}$ \\
\hline $\begin{array}{l}\text { 3. Actively promote interprofes- } \\
\text { sional collaboration for holistic } \\
\text { management of NCDs }\end{array}$ & $\begin{array}{l}\text { - Facilitate effective multidisciplinary treat- } \\
\text { ment of NCDs through joint education/ } \\
\text { training sessions, shared document pro- } \\
\text { cessing platforms, clinical decision sup- } \\
\text { port and defined referral pathways } \\
\text { - Engage family members/caregivers as } \\
\text { peer support workers }\end{array}$ & $\begin{array}{l}\text { Government, private sector, academia, } \\
\text { HCPs, nurses, allied health professionals, } \\
\text { patient and family }\end{array}$ & $\begin{array}{l}\text { - Hospitalization rates due to } \\
\text { NCDs } \\
\text { - Biochemical risk factors (high } \\
\text { blood sugar, high BMI, high BP, } \\
\text { and high blood lipids) } \\
\text { - Number of venues available } \\
\text { for patients and their family's } \\
\text { co-participation }\end{array}$ \\
\hline $\begin{array}{l}\text { 4. Strengthen the role of phar- } \\
\text { macists and other allied health } \\
\text { professionals in NCD preven- } \\
\text { tion and care }\end{array}$ & $\begin{array}{l}\text { - Build capability of pharmacists and other } \\
\text { allied health professionals through accre- } \\
\text { dited trainings to screen, counsel and } \\
\text { monitor NCD outcomes } \\
\text { - Develop specialist referral pathways for } \\
\text { pharmacists }\end{array}$ & $\begin{array}{l}\text { Government and private sector, } \\
\text { professional organizations, HCPs, nurses, } \\
\text { pharmacists, pharmaceutical sector, } \\
\text { technology companies, individuals and } \\
\text { caregivers }\end{array}$ & $\begin{array}{l}\text { - Percent of patients counselled } \\
\text { on their medications by phar- } \\
\text { macists and other allied health } \\
\text { professionals } \\
\text { - Number of trained pharma- } \\
\text { cists who can prescribe } \\
\text { medicines } \\
\text { - Number of pharmacies with } \\
\text { point-of-care NCD screening } \\
\text { capabilities }\end{array}$ \\
\hline $\begin{array}{l}\text { 5. Reform health professions } \\
\text { education (HPE) curricula to } \\
\text { enhance clinical practice for } \\
\text { improved mental health } \\
\text { management }\end{array}$ & $\begin{array}{l}\text { Reorient training curricula towards iden- } \\
\text { tification and management of common } \\
\text { mental health problems for physicians, } \\
\text { nurses and pharmacists } \\
\text { Train health workers to screen for and } \\
\text { identify mental health problems among } \\
\text { constituents in schools and colleges }\end{array}$ & $\begin{array}{l}\text { Government and private sector, academia, } \\
\text { education board, schools and community }\end{array}$ & $\begin{array}{l}\text { - Number of physicians, nurses } \\
\text { and pharmacists trained with } \\
\text { the revised curricula } \\
\text { - Number of trained personnel } \\
\text { in schools and colleges } \\
\text { equipped to screen for mental } \\
\text { health problems }\end{array}$ \\
\hline $\begin{array}{l}\text { 6. Enhance monitoring of NCD } \\
\text { risk factors using evidence- } \\
\text { based technology }\end{array}$ & $\begin{array}{l}\text { Develop a robust national implementa- } \\
\text { tion framework for evidence-based } \\
\text { technology for health care } \\
\text { - Promote disease surveillance through use } \\
\text { of smartphone-based apps and home- } \\
\text { based medical devices for measuring BP, } \\
\text { blood sugar and BMI } \\
\text { - Generate and disseminate evidence on } \\
\text { the efficacy and effectiveness of techno- } \\
\text { logical solutions in improving clinical } \\
\text { outcomes }\end{array}$ & $\begin{array}{l}\text { Government, technology companies, } \\
\text { pharmaceutical sector, health insurance } \\
\text { companies and data scientists }\end{array}$ & $\begin{array}{l}\text { - Rate of premature mortality } \\
\text { and hospitalizations due to } \\
\text { NCDs among the population } \\
\text { using technology-based } \\
\text { interventions } \\
\text { - Percent of people with NCDs } \\
\text { using evidence-based technol- } \\
\text { ogy for health care }\end{array}$ \\
\hline
\end{tabular}

Abbreviations: ASEAN, Association of Southeast Asian Nations; BMI, body mass index; BP, blood pressure; HCPs, healthcare professionals; HPE, health professions curricula; NCD, noncommunicable disease; SDM, shared decision-making.

Essential NCD Intervention (PhilPEN) protocol. ${ }^{45}$ As of February 2017, >600,000 patients were registered under these clubs. ${ }^{46}$ This initiative is planned to be scaled up nationwide with the clubs also serving as community support groups to disseminate information on adequate control of BP and blood sugar.

\section{Introduce Health Promotion Programs in Schools,} Universities, Workplaces, and Public Places

\section{Regional Context}

Asia had half of all overweight and obese children under five years of age in 2014. ${ }^{47} \mathrm{~A}$ high prevalence of NCD risk factors was observed among male and female university 
students from nine ASEAN member states (obesity: $28 \%$ and $17 \%$; low physical activity: $39 \%$ and $53 \%$; tobacco use: $7 \%$ and $3 \%$ ) which was attributed to poor awareness among the students. ${ }^{48}$ A study of education program on salt intake reduction targeting school children demonstrated positive outcomes such as decreased BP among children and their families. ${ }^{49}$ The WHO Global Action Plan for the prevention and control of NCDs (2013-2020) advocates policies promoting healthy food in all public institutions, including schools, colleges and workplaces. ${ }^{50}$ Effective implementation of such policies will help in meeting the WHO targets related to reduction in salt intake, halt in the rise of diabetes and obesity and reduced prevalence of raised $\mathrm{BP}^{50}$

\section{Case Study}

In Vietnam, $80 \%$ of salt intake comes from cooking condiments rather than from processed food. ${ }^{51}$ Therefore, reducing salt intake needs population behavior change strategies. A behavior change program, Communication for Behavioral Impact-Eat Less Salt (COMBI-ELS), was organized in eight Vietnamese villages between 2013 and 2014 and included media campaigns, school interventions and community programs focused on high-risk groups. ${ }^{51}$ Within one year, the average salt intake reduced from $9.4 \mathrm{~g} /$ day to $7.4 \mathrm{~g} /$ day. There was increased awareness among people on the association of hypertension ( $43.6 \%$ to $86 \%)$ and stroke $(9.2 \%$ to $46.6 \%)$ with high salt intake. ${ }^{51}$ The success of this program led to implementation of a national action plan for dietary salt intake reduction to control NCDs.

\section{Pass and Implement Legislation to Reduce NCD RISK Factors (Tobacco Use, Excessive Alcohol Use and Salt Intake) \\ Regional Context}

Growing evidence suggests that intervention strategies, such as taxation, can effectively tackle the leading causes of NCDs and their underlying risk factors. ${ }^{14,52}$ The population-based "best-buys" for NCD behavioral risk factors (tobacco, alcohol, diet, and physical activity) account for a small fraction of the total cost of the "best buys". ${ }^{14}$ Increasing the cost of tobacco products has the highest impact on reducing its demand and taxes are the most direct way to influence the cost of tobacco products. ${ }^{52}$ In LMICs, the most cost-effective "best buy" interventions are increased taxes on tobacco products, alcoholic beverages, and sugar-sweetened beverages. ${ }^{14}$

\section{Case Study}

In 2012, the Philippine government implemented tax reforms ("sin tax") on all tobacco and alcohol products to discourage smoking and consumption of excessive alcohol. ${ }^{53}$ Comparison of tobacco use prevalence at two time points revealed that the prevalence decreased from $30 \%$ in 2009 to $24 \%$ in $2015 .{ }^{54}$ Additionally, the average household cigarette consumption reduced from 62 packs in 2009 to 52 packs in 2015 and evidence suggested that "sin tax" accounted for $\sim 70 \%$ of the actual decline in cigarette consumption. ${ }^{54}$ A simulation study reported that updating taxes on alcohol products may reduce alcohol consumption $\leq 20 \%$ within four years from $2018 .{ }^{55}$ Other benefits of the "sin tax" include increased revenue available to fund UHC programs which could reach poor and indigenous populations in geographically isolated and disadvantaged areas (GIDAs). The Philippines Department of Health budget increased from USD 1.1 billion (PHP 53.2 billion) in 2013 to USD 3.2 billion (PHP 165 billion) in 2019 with "sin tax" contributing 55\% of the total budget. ${ }^{56}$ In 2018, the "sin tax" was expanded to include sugar-sweetened drinks. ${ }^{57}$

\section{Provide an Encouraging Physical and Social Environment for People to Practice Healthy Habits and Incentivize Healthy Lifestyle \\ Regional Context}

The major modifiable risk factors for NCDs can be combated, partly, by adopting a healthy lifestyle. ${ }^{50}$ Incentivizing healthy behavior can drive sustainable behavioral modifications that will alleviate NCD burden. ${ }^{58}$ The urban environment poses additional difficulty in the practice of healthy lifestyle and city dwellers are challenged with sanitation, air pollution and access to healthy food and safe spaces. Policies such as creating smoke-free spaces, reducing air pollution and improving infrastructure for walking and cycling can help create environments that support better health outcomes. This requires collaboration with health, transport, housing and education sectors also referred to as the "Health-in-all polices approach". 59

\section{Case Study}

Under the Healthy Cities concept, Marikina City, Philippines implemented several programs aimed at improving the physical and social environments supportive of health promotion. ${ }^{60}$ Several initiatives in partnership with the public, private and voluntary sectors of society were undertaken: healthy streets with walkable roadways and extensive 
bicycle network, healthy markets which are clean, accessible and have food testing facilities, healthy schools with a healthy feeding program and free health checkups conducive for learning among others. Since 2004, Marikina City has received various awards, including one from the WHO, for "Outstanding Healthy City". 60 The City of Marikina was one of the founding members of the WHO Alliance for Healthy Cities initiative established in 2003.

\section{Integrate Mental Health in the Management of Chronic Conditions in Primary Care Settings Regional Context}

The treatment gap, or the difference between the number of people needing care vs those receiving care, ranges from 50 $90 \%$ for mental disorders in the ASEAN region. ${ }^{61}$ Close links between NCDs and mental disorders, particularly CVD and depression, are well established. ${ }^{2,62}$ Patients with psychiatric comorbidities have longer treatment duration and poor outcomes. ${ }^{2}$ Despite this evidence, cardiovascular risk assessment does not include depression. ${ }^{62}$ Given the overlapping risk factors between mental disorders and other NCDs, integrated management of both conditions can reduce the associated disability. ${ }^{2}$ The lack of primary care facilities, policy implementation and trained health workers together with the associated stigma hinder access to mental health treatment. ${ }^{63}$ Simple and cost-effective tools such as Patient Health Questionnaire-2 for mental health screening and the WHO Package of Essential Noncommunicable Disease Interventions can be easily deployed in lowresource primary care settings to reduce NCD risk factors. $^{64,65}$ Integrating mental health treatment into the NCD collaborative care model in LMICs has demonstrated improvement in quality of care and patient outcomes. ${ }^{66}$

\section{Case Study}

In 2008, Thailand had an estimated 1.5 million people with depression and the rate of suicide was six per 100,000 population. ${ }^{67}$ The Surveillance System of Depressive Disorders (SDDP) set up in 2006 was the first nationwide mental health program in Thailand with a framework for depression intervention focused on awareness, training, research, and national health policy advocacy. ${ }^{67}$ Simple instruments for screening at-risk populations and preventing relapse and clinical practice guidelines for primary care were developed as part of the program. Until 2016, $>14$ million people were screened and received mental health education. ${ }^{67}$ Access to services for depressive disorders increased from 5.1\% in 2009 to $48.5 \%$ in 2016 across public health services. ${ }^{67}$

\section{Theme 2: Addressing NCD Clinical and Public Health Practice Gaps in the ASEAN Region}

\section{Set Up Local Public and Private Primary Care} Networks

\section{Regional Context}

As the most frequent entry point for patients, primary care has the greatest potential to screen and identify high-risk patients. Efficient use of limited healthcare facilities and human resources, sustainable health financing mechanisms, access to basic diagnostics, essential medicines, organized medical information and effective referral systems are imperative to ensure an equitable primary healthcare in LMICs. ${ }^{65}$

\section{Case Study}

It is estimated that a quarter of all adult Thais have hypertension and only one-third have their BP under control. $^{68}$ Despite extensive screening, about half of all patients remain undiagnosed due to patient or health systems factors. ${ }^{68}$ The public sector accounts for $>70 \%$ of health facilities in Thailand. ${ }^{69}$ The Government of Thailand included free screening, diagnosis, treatment and laboratory monitoring for hypertension to everyone within the primary healthcare system as part of UHC, in 2002 . $^{69}$ Some of the best practices for providing hypertension care includes a unique identification card to maintain electronic health record and facilitate follow-up for every patient, opportunistic screening at every outpatient visit, patient-centric care provided closer to home, functional referral linkages, regular drug supply and 3-month prescriptions, and availability of dedicated team of welltrained staff at all levels. ${ }^{69}$ In $2019,88 \%$ of all eligible Thai population had their BP screened at the community level. ${ }^{69}$ Each month about 50,000-70,000 new cases are diagnosed from all public health facilities and BP control has doubled from $24 \%$ in 2004 to $50 \%$ in $2014 .^{69}$ About $80 \%$ of patients received treatment within reasonable distance $(\sim 7 \mathrm{~km})$ from their homes, in $2019 .{ }^{69}$ To further increase access to screening, diagnosis and treatment of hypertension for the working population, measures to reduce diagnostic and treatment inertia and collaboration with the private sector are proposed. 
Improve Treatment Adherence Using Evidence-Based and Innovative Solutions

\section{Regional Context}

Adherence denotes active participation of patients in their therapeutic plan, whereas compliance suggests passively following the plan. ${ }^{70}$ Medication adherence is influenced by the patient, disease condition, therapy, healthcare ecosystem and socioeconomic factors. Adherence to antidepressants remains as low as $60 \%$ within 6 months of starting treatment. ${ }^{71}$ Collaborative care approach where each professional contributes towards the patient journey by providing multiple opportunities to receive critical messages can be instrumental in improving adherence. Nonadherence to antidepressants is strongly associated with patients' perceptions of their relationships with HCPs, including a lack of shared decision-making (SDM) or trust. ${ }^{72}$ Lack of a structured flow, time and patient aids are the key challenges faced by doctors in implementing SDM. The biopsychosocial model of care emphasizes patient centricity as the guiding principle to strengthen "therapeutic alliance" and medication adherence.

\section{Case Study}

The SDM concept was introduced in Malaysia in 2010. Despite government efforts to promote patient-centricity in decision-making, SDM lacks widespread implementation. ${ }^{73}$ A shared/collaborative role in decision-making is preferred by Malaysian patients in urban setting (51\%), 28\% in rural setting and $32 \%$ of adolescents. ${ }^{73} \mathrm{~A}$ focus group study involving 19 psychiatrists and 11 patients with major depressive disorder was conducted at an urban teaching hospital in Malaysia to develop a strategic tool for SDM in the use of antidepressants. ${ }^{74}$ The tool included a booklet of scripts for doctors which was adapted from the "Elwyn's three-talk model of shared decision-making" and a patient decision aid prior to "team talk". ${ }^{75}$ The model depicts conversational steps, initiated by providing support when introducing options, followed by strategies to compare and discuss tradeoffs, before deliberation based on informed preferences. ${ }^{75}$

\section{Actively Promote Interprofessional Collaboration for Holistic Management of NCDs \\ Regional Context}

Interprofessional collaboration is the coordinated care of patients by a team of HCPs, which is interactive, additive and holistic in nature. ${ }^{76}$ Patients with NCDs frequently have multiple, comorbid long-term conditions requiring holistic treatment. Collaborative care integrates patients and families in the healthcare delivery system resulting in higher treatment satisfaction, compliance and treatment performance. ${ }^{77}$ Patients who have recovered or are recovering can be trained as peer support specialists to form part of multidisciplinary treatment teams. The major barriers to implementing a collaborative care approach are a lack of understanding of roles and responsibilities for different team members, lack of confidence in the benefits of interprofessional care, and inertia of traditional practice ("health care silos"). ${ }^{76}$ Collaborative care can be supported by joint education sessions, shared document processing and appointments, and incentives.

\section{Case Study}

In 2005, Asia had the highest number people with diabetes, with a disproportionate increase in diabetes among the young and middle-aged population. ${ }^{78}$ Protocol-driven multidisciplinary care reduced the risk of clinal outcome by $50-70 \%$ in diabetes vs standard care. ${ }^{78}$ Joint Asia Diabetes Evaluation (JADE) was set up in 2007 as the first web-based collaborative program to improve ambulatory diabetes care and implemented in Taiwan, Singapore, Thailand, and Philippines among other countries. JADE incorporated a validated risk engine, evidence-based care protocol, clinical decision support and personalized reporting to support team-based integrated care. ${ }^{78}$ Importantly, JADE e-portal is utilized by health care teams to create diabetes registry to detect defaults, monitor clinical progress and track performance indices of patients for continuous quality improvement. ${ }^{78}$ Implementation of JADE is estimated to lower hospitalization rates by $20-50 \%$ and reduce healthcare costs by USD 242/patient/year (HKD $1,876 /$ patient/year) compared with standard care. ${ }^{79,80}$

\section{Strengthen the Role of Pharmacists and Other Allied Health Professionals in NCD Prevention and Care \\ Regional Context}

The WHO emphasizes the important role of pharmacies in the primary healthcare network to provide early screening and testing, advanced counselling and long-term chronic disease management. ${ }^{81}$ As the most accessible primary HCPs, community pharmacists remain an integral part of the multidisciplinary team for optimizing NCD care. Pharmacists are ideally placed to implement public health programs, lead point-of-care NCD screening programs, improve patients' adherence, educate patients and caregivers on disease management, and assist in medication review and correct use of devices. ${ }^{81}$ 


\section{Case Study}

Increasing healthcare costs and an ageing population in Singapore needs evolved pharmacy services to meet the increasing healthcare burden and provide cost-effective health care. ${ }^{82}$ The National Pharmacy Strategy is a 10year national plan by Singapore Ministry of Health to transform the pharmacy profession. ${ }^{82}$ The initiative has a focus on five key areas: enhancing pharmacy-led valuebased healthcare services to the community; restructuring training and education programs for a skilled pharmacy workforce; redesigning a seamless, accessible and affordable supply chain for medication delivery at every point-of -care; providing information-sharing platform for clinical and practice-based research; and enabling technology to deliver care across settings. ${ }^{82}$ Under this strategy, the National University of Singapore launched a National Collaborative Prescribing Programme in 2018 to train senior pharmacists and advanced practice nurses so they may independently prescribe medicines and order tests for patients. ${ }^{83}$

\section{Reform Health Professions Education (HPE) Curricula to Enhance Clinical Practice for Improved Mental Health Management}

\section{Regional Context}

In the ASEAN region, only $30 \%$ of the countries provide mental health training to primary care doctors and only half of the countries have officially approved training manuals in most primary healthcare clinics. ${ }^{84} \mathrm{WHO}$, with an aim to close the mental health treatment gap, recommends integrating mental health services into primary health care, which can be accomplished by reforming the mental health training. ${ }^{85}$ The stigma associated with mental disorders prevents adolescents and their guardians from seeking help at psychiatric hospitals or mental health centers. Altogether, training primary care doctors and schoolteachers and staff in suicide prevention is a top priority to recognize at-risk adolescents and get them further counselling.

\section{Case Study}

Singapore reported a six-fold rise in adolescent psychiatric cases between 1980 and $2000 .^{86}$ In 2010, mental disorders were the largest contributor of disability among children $<15$ years old in Singapore. ${ }^{86}$ Response, Early Intervention and Assessment in Community Mental Health (REACH) is a collaborative program launched in 2007 by the Singapore Ministry of Education, Institute of Mental Health and two other hospitals to implement mental health services in all registered schools. ${ }^{86}$ The program aimed to increase accessibility of mental health support to at-risk students by enhancing the capacity of schools with trained personnel to support these students and building community support networks. Between 2007 and 2015, 4184 students were referred to REACH by school counsellors; 955 of these students were referred to tertiary care. Within six months, the clinical outcome of the students improved as assessed by counsellors/ teachers. ${ }^{86} \mathrm{REACH}$, a community-based care program, was more cost-effective than hospital-based care. ${ }^{86}$

\section{Enhance Monitoring of NCD Risk Factors Using Evidence-Based Technology \\ Regional Context}

Increasing smartphone usage accompanied with decreasing device and telecommunication service prices offer cost-effective opportunities for e-health and m-health technologies in resource-constrained economies. Information and communication technologies can transcend geographic barriers between patients and physicians-facilitating patient communications, enhancing diagnoses and treatments, improving data management, streamlining financial transactions and preventing counterfeit medicine supply. ${ }^{87}$ However, there is a dearth of high-quality scientific evidence for the clinical benefits of technology-based health monitoring apps which needs to be overcome.

\section{Case Study}

In 2016, CVD accounted for a third of all deaths in Indonesia. ${ }^{88}$ The government developed a policy for preventing and managing CVD through advocacy, health promotion, and health system strengthening particularly at district health agencies. Systematic Medical Appraisal Referral and Treatment (SMARThealth) - a multifaceted mobile technology-supported primary healthcare interventions was evaluated in populations from eight rural villages in Indonesia. ${ }^{88}$ The mobile application enabled primary healthcare nurses and physicians and community healthcare workers to collect patient information using basic equipment, assess individuals' risk status, receive tailored decision support, provide lifestyle advice and refer high-risk individuals to nurses and physicians. Use of SMARThealth interventions led to a significantly greater proportion of high-risk rural Indonesian population achieving systolic BP target $<140 \mathrm{mmHg}$ than those without the intervention $(31.0 \%$ vs $22.2 \%$, adjusted relative risk 1.3 ; $95 \%$ CI: $1.2-1.5 ; p<0.001) .{ }^{88}$ These effects were 
driven by a greater use of preventive CVD medications among high-risk individuals receiving SMARThealth interventions compared with individuals without the intervention $56.8 \%$ of individuals in the intervention villages used BP medication vs $15.7 \%$ of individuals in the control villages). ${ }^{88}$

\section{Discussion}

Most (73\%) Southeast Asian countries have treatment guidelines for the four major NCDs (CVD, diabetes, cancers, and chronic respiratory diseases). ${ }^{89}$ All 11 countries from the Southeast Asian region also have a national NCD policy/ strategy/action plan, though the integrated plan is operational in only $80 \%$ of the countries in the region. ${ }^{89}$ These variations in NCD policy implementation influence the national capacity of healthcare systems to effectively tackle NCDs. The most widespread policy gaps in the region are inadequate surveillance of NCDs and their risk factors, suboptimal health insurance coverage, lack of trained healthcare personnel and limited primary care capacity. ${ }^{6,90}$ Addressing gaps in NCD prevention and management in the ASEAN member states requires innovative multisectoral public-private partnerships, "whole-of-government" approach, "whole-ofsociety" approach and "health-in-all policies" to provide cost-effective, efficient and quality health services (Table 4). ${ }^{91}$ Participation of citizens remains integral to these efforts in filling the lacunae in NCD management. Awareness of NCD risk factors and mental health management should be introduced at an early age to help imbibe optimal practices to prevent the rise in NCDs.

Countries in the ASEAN region rely both on public and private primary healthcare services for NCD care delivery. ${ }^{92}$ Most ASEAN member states have integrated the basic management of the four major NCDs into primary health care. However, the existing primary health care systems lack the capacity to consistently provide essential preventive interventions for NCDs, long-term chronic care for NCDs and associated comorbidities, and adequate mental health management services. ${ }^{93,94}$ The acute shortage of human resources and treatment facilities for mental health in Southeast Asian countries combined with low rates of overall medication adherence in Asian populations further contribute to the NCD treatment gap. ${ }^{94}$ The proposed solutions for addressing clinical and public health practice gaps in NCD management require strengthening primary care services, employing collaborative care approach, expanding the roles of primary care HCPs and pharmacists, and developing technology-based based healthcare solutions (Table 5). Population-based and clinical approaches to prevent NCDs need to be prioritized both in urban and rural areas. ${ }^{93}$

In 2013, the ASEAN member states adopted the Bandar Seri Begawan Declaration on NCDs in ASEAN. ${ }^{95}$ The declaration highlighted the need to accelerate actions to reduce NCDs through engagement of multiple stakeholders including the private sector, intensification of NCD screening and health promotion activities, strengthening health systems capacity, enhancing efforts toward achieving the WHO voluntary targets for NCD prevention and control, advancing UHC and adopting health-in-all policies. ${ }^{95}$ At a subsequent meeting in 2017, the ASEAN member states renewed their commitment to the declaration while highlighting the rising prevalence of NCDs and their risk factors as well as the interventions and best practices implemented by the member states to prevent risk factors and promote health through the delivery of relevant health services. ${ }^{96}$

NCD care must move towards an interprofessional, collaborative, transdisciplinary approach with seamless sharing of knowledge and decision-making to improve effectiveness and efficiency in NCD care. ${ }^{97}$ Inclusion of patients, their families and communities is vital to a successful continuum of NCD care. ${ }^{97}$ It is encouraging to note the overlap between the recommendations from this paper and the recent recommendations from an independent WHO high-level commission including empowering individuals by providing health promoting environment, incorporating NCDs and mental health as essential components of UHC and partnering with businesses to mount effective NCD responses. ${ }^{98}$

\section{Study Limitations}

There are several limitations to our study. First, though the ASEAN region comprises 10 countries, our recommendations were based on insights from experts representing six ASEAN member states ( $\sim 95 \%$ of the ASEAN population). ${ }^{99}$ Second, the case studies presented in this paper were provided by selected experts from the region and located via literature search. However, there may be other successful case studies in the region which are not reported here. The case studies showed good practices which need to be contextualized within the local culture and health care settings of respective countries and further validated for implementation in another country. Some of the case studies have not shown definitive measures of improvement in clinical or cost-effectiveness outcomes; and such outcomes still need to be determined. Lastly, while this paper focuses on cardiovascular and mental disorders, these recommendations 
maybe extended to other NCDs such as diabetes, cancer and chronic respiratory diseases as the NCD risk factors tend to cluster together. ${ }^{2}$

\section{Conclusion and Future Directions}

Identifying implementation challenges and proposing solutions for national and local NCD planning requires a multistakeholder approach, which was addressed in this study, partly, by engaging a multidisciplinary expert group. Further operationalization of the recommendations included in this paper requires commitment and participation from other stakeholders such as policy makers. ${ }^{100}$ The implementation of NCD programs can be supported through publicprivate partnerships; however, successful partnerships need an established regulatory framework and clearly outlined goals. ${ }^{101}$ Evidence-based digital technologies have the potential to improve care coordination, prevent hospitalizations and reduce health wastage. ${ }^{102}$ Technologies such as artificial intelligence have shown promise in assisting clinical decision support, however these digital solutions need to be rigorously evaluated for safe and effective as well as ethical integration. ${ }^{103}$ Further research on patient beliefs and health-seeking behavior in low-income settings and their effect on healthy lifestyle can help tailor more effective NCD prevention programs for the ASEAN region. ${ }^{104,105}$

\section{Acknowledgments}

The authors would like to thank Tanaya Bharatan, Scientific Communications, Pfizer, and Kaveri Sidhu, Scientific Communications, Pfizer for providing medical writing support funded by Pfizer.

\section{Author Contributions}

All authors made substantial contributions to conception and design, acquisition of data, or analysis and interpretation of data; took part in drafting the article or revising it critically for important intellectual content; gave final approval of the version to be published; and agree to be accountable for all aspects of the work.

\section{Funding}

This manuscript is based on the insights gathered at two face-to-face meetings which were sponsored by Pfizer. The development of this manuscript was funded by Pfizer. The view and opinions expressed in this manuscript are those of the authors.

\section{Disclosure}

NTC has received personal fees from Pfizer for this work and received grant and personal fees from Pfizer, consultancy fees from United Laboratories (UNILAB) and personal fees from Johnson \& Johnson (Philippines) outside of the submitted work. RB has received personal fees for lectures from Pfizer (Philippines). YCC has received grants, personal fees and nonfinancial support from Pfizer. DVD has received personal fees and travel support from MSD, Pfizer and AstraZeneca and received personal fees from Nestlé, Roche, Sandoz, Novartis and Astra-Zeneca. CHN has received personal fees from Pfizer. YR has received meeting honorarium from Pfizer. HZ has received nonfinancial support from Pfizer as an invited speaker. GEB, PR, MT and AM are employees of Pfizer. GEB, PR and AM also hold shares in Pfizer. The authors report no other conflicts of interest in this work.

\section{References}

1. Noncommunicable diseases in the South-East Asia. 2019. Available from: http:/www.searo.who.int/entity/noncommunic able_diseases/en/. Accessed January, 2020.

2. Stein DJ, Benjet C, Gureje $\mathrm{O}$, et al. Integrating mental health with other non-communicable diseases. BMJ. 2019;364:1295. doi:10.1136/bmj.1295

3. Dhillon PK, Jeemon P, Arora NK, et al. Status of epidemiology in the WHO South-East Asia region: burden of disease, determinants of health and epidemiological research, workforce and training capacity. Int J Epidemiol. 2012;41(3):847-860. doi:10.1093/ije/ dys046

4. Institute for Health Metrics and Evaluation. GBD Compare (Viz Hub). 2019. Available from: https://vizhub.healthdata.org/gbdcompare/. Accessed January, 2020.

5. Frenk J, Gómez-Dantés O. The triple burden: disease in developing nations. Harvard Int Rev. 2011;33(3):5.

6. Dans A, Ng N, Varghese C, Tai ES, Firestone R, Bonita R. The rise of chronic non-communicable diseases in southeast Asia: time for action. Lancet. 2011;377(9766):680-689. doi:10.1016/S0140-6736(10) 61506-1

7. Castillo-Carandang NT. Kagalingan: The Filipino's Search for Well-Being, Happiness and Health. Amsterdam: Universiteit van Amsterdam; 2019.

8. Noncommunicable diseases and mental health. Noncommunicable Diseases Country Profiles 2018. World Health Organization. 2018. Available from: https://www.who.int/ $\mathrm{nmh} /$ countries/en/. Accessed January, 2020.

9. Low WY, Lee YK, Samy AL. Non-communicable diseases in the Asia-Pacific region: prevalence, risk factors and community-based prevention. Int J Occup Med Environ Health. 2015;28(1):20-26. doi:10.2478/s13382-014-0326-0

10. Rijal A, Adhikari TB, Khan JAM, Berg-Beckhoff G. The economic impact of non-communicable diseases among households in South Asia and their coping strategy: a systematic review. PLoS One. 2018;13(11):e0205745. doi:10.1371/journal.pone.0205745

11. World Economic Forum and Harvard School of Public Health. From burden to "best buys": reducing the economic impact of NCDs in low- and middle-income countries. 2011. Available from: https://www.who.int/nmh/publications/best_buys_sum mary.pdf?ua=1. Accessed January, 2020. 
12. World Economic Forum. Harvard School of Public Health. The Global economic burden of non-communicable diseases. 2011. Available from: http://www3.weforum.org/docs/WEF_Harvard_ HE_GlobalEconomicBurdenNonCommunicableDiseases_2011. pdf. Accessed January, 2020.

13. Abegunde DO, Mathers CD, Adam T, Ortegon M, Strong K. The burden and costs of chronic diseases in low-income and middle-income countries. Lancet. 2007;370(9603):1929-1938. doi:10.1016/S0140-6736(07)61696-1

14. Tackling NCDs: 'Best buys' and Other Recommended Interventions for the Prevention and Control of Noncommunicable Diseases. 2017. Available from: https://apps.who.int/iris/bitstream/ handle/10665/259232/WHO-NMH-NVI-17.9-eng.pdf?sequence= 1 \&isAllowed=y. Accessed January, 2020.

15. Allen LN, Pullar J, Wickramasinghe KK, et al. Evaluation of research on interventions aligned to WHO 'Best Buys' for NCDs in low-income and lower-middle-income countries: a systematic review from 1990 to 2015. BMJ Glob Health. 2018;3(1):e000535. doi:10.1136/bmjgh-2017-000535

16. The Global Health Observatory. World Health Organization. 2020. Available from: https://www.who.int/data/gho. Accessed May, 2020.

17. Global Health Expenditure Database. 2017; http://apps.who.int/ nha/database/country_profile/Index/en. Available from: Accessed January, 2020.

18. The 2018 Update, Global Health Workforce Statistics. Geneva: World Health Organization; 2018. Available from: https://apps. who.int/gho/data/node.main.HWFGRP?lang=en. Accessed May, 2020.

19. Essential Medicines and Basic Health Technologies for Noncommunicable Diseases: Towards a Set of Actions to Improve Equitable Access in Member States. 2015. Available from: https:// www.who.int/nmh/ncd-tools/targets/Final_medicines_and_technolo gies_02_07_2015.pdf. Accessed January, 2020.

20. Van Minh H, Pocock NS, Chaiyakunapruk N, et al. Progress toward universal health coverage in ASEAN. Glob Health Action. 2014;7(1):25856. doi:10.3402/gha.v7.25856

21. Myint CY, Pavlova M, Thein KN, Groot W. A systematic review of the health-financing mechanisms in the Association of Southeast Asian Nations countries and the People's Republic of China: lessons for the move towards universal health coverage. PLoS One. 2019;14 (6):e0217278. doi:10.1371/journal.pone.0217278

22. Tien NTK, Tuan PL, Hung DV, et al. Joint annual health review: towards healthy ageing in Vietnam. 2017. Available from: http:// jahr.org.vn/downloads/JAHR2016/JAHR2016_Edraft.pdf. Accessed January, 2020.

23. Agustina R, Dartanto T, Sitompul R, et al. Universal health coverage in Indonesia: concept, progress, and challenges. Lancet. 2019;393 (10166):75-102. doi:10.1016/S0140-6736(18)31647-7

24. Coker RJ, Hunter BM, Rudge JW, Liverani M, Hanvoravongchai P. Emerging infectious diseases in southeast Asia: regional challenges to control. Lancet. 2011;377(9765):599-609. doi:10.1016/S01406736(10)62004-1

25. Noncommunicable Diseases in the South-East Asia Region. 2011. Available from: http://apps.searo.who.int/PDS_DOCS/B4793.pdf. Accessed January, 2020.

26. Lim J, Chan MM, Alsagoff FZ, Ha D. Innovations in non-communicable diseases management in ASEAN: a case series. Glob Health Action. 2014;7(1):25110. doi:10.3402/gha.v7.25110

27. Ezzati M, Pearson-Stuttard J, Bennett JE, Mathers CD. Acting on non-communicable diseases in low- and middle-income tropical countries. Nature. 2018;559(7715):507-516. doi:10.1038/s41586018-0306-9
28. NCD. Countdown collaborators. NCD Countdown 2030: worldwide trends in non-communicable disease mortality and progress towards Sustainable Development Goal target 3.4. Lancet. 2018;392 (10152):1072-1088. doi:10.1016/S0140-6736(18)31992-5

29. Martinez-Raga J, Amore M, Di Sciascio G, et al. 1st International experts' meeting on agitation: conclusions regarding the current and ideal management paradigm of agitation. Front Psychiatry. 2018;9:54. doi:10.3389/fpsyt.2018.00054

30. Braun V, Clarke V. Using thematic analysis in psychology. Qual Res Psychol. 2006;3(2):77-101. doi:10.1191/1478088706qp063oa

31. Nakamura K, Barzi F, Lam TH, et al. Cigarette smoking, systolic blood pressure, and cardiovascular diseases in the Asia-Pacific region. Stroke. 2008;39(6):1694-1702. doi:10.1161/STROKEAHA. 107.496752

32. Yusuf S, Hawken S, Ounpuu S, et al. Obesity and the risk of myocardial infarction in 27,000 participants from 52 countries: a case-control study. Lancet. 2005;366(9497):1640-1649. doi:10.1016/S0140-6736(05)67663-5

33. Lawes CM, Parag V, Bennett DA, et al. Blood glucose and risk of cardiovascular disease in the Asia Pacific region. Diabetes Care. 2004;27(12):2836-2842.

34. Barzi F, Patel A, Woodward M, et al. A comparison of lipid variables as predictors of cardiovascular disease in the Asia Pacific region. Ann Epidemiol. 2005;15(5):405-413.

35. Asia Pacific Cohort Studies Collaboration. Cholesterol, diabetes and major cardiovascular diseases in the Asia-Pacific region. Diabetologia. 2007;50(11):2289-2297. doi:10.1007/s00125-0070801-2

36. Kontis V, Mathers CD, Rehm J, et al. Contribution of six risk factors to achieving the $25 \times 25$ non-communicable disease mortality reduction target: a modelling study. Lancet. 2014;384 (9941):427-437. doi:10.1016/S0140-6736(14)60616-4

37. Lim KH, Fadhli M, Omar M et al. Technical report: evaluation of effectiveness of implementation of "Komuniti Sihat Perkasa Negara" (KOSPEN) programme in Malaysia- Phase 1. 2015. Available from: http://iku.moh.gov.my/images/IKU/Document/ REPORT/2014/KOSPEN2014.pdf. Accessed January, 2020.

38. National Strategic Plan for Non-Communicable Disease: Medium Term Strategic Plan to Further Strengthen the NCD Prevention and Control Program in Malaysia (2016-2025) 2016. Available from: https://www.iccp-portal.org/system/files/plans/MYS_B3 NSP\%20NCD\%202016-2025\%2C\%20FINAL.pdf. Accessed May, 2020.

39. Ling MY, Wan Shakira RH, Rosnah R, et al. Knowledge and acceptance of community health intervention program in Sothern zone in Peninsular Malaysia among District Health Officers and KEMAS District Officers. Medical Journal of Malaysia. 2015;70 (Supplement): 1 .

40. Global NCD Target: Improve Access to Technologies and Medicines to Treat NCDs. 2016. Available from: https://www. who.int/beat-ncds/take-action/policy-brief-improve-medicineaccess.pdf. Accessed January, 2020.

41. Peltzer K, Pengpid S. Utilization and practice of Traditional/ Complementary/Alternative Medicine (T/CAM) in Southeast Asian Nations (ASEAN) member states. Stud Ethno-Med. 2015;9(2):209-218. doi:10.1080/09735070.2015.11905437

42. Mattke S, Haims MC, Ayivi-Guedehoussou N, et al. Improving access to medicines for non-communicable diseases in the developing world. Rand Health Q. 2011;1(3):1.

43. Galema NA Hypertension and diabetes clubs in the government agencies. 2019. Available from: https://www.pulsus.com/proceed ings/hypertension-and-diabetes-clubs-in-the-government-agencies -699.html. Accessed January, 2020. 
44. Geroy LS. Economic evaluation for first-line anti-hypertensive medicines: applications for the Philippines. Cost Eff Resour Alloc. 2012;10(1):14. doi:10.1186/1478-7547-10-14

45. Free maintenance meds at DOH's Hypertension and Diabetes Club. 2016. Available from: https://www.rappler.com/nation/ 118965-free-maintenance-medicines-doh-hypertension-diabetesclub. Accessed January, 2020.

46. Republic of the Philippines. Department of Health. Press Release. Please be careful with your heart, choose healthy options this Valentine's day. 2017. Available from: https://www.doh.gov.ph/ node/9296. Accessed January, 2020.

47. Report of the Commission on Ending Childhood Obesity. 2016 Available from: https://apps.who.int/iris/bitstream/handle/10665/ 204176/9789241510066_eng.pdf?sequence=1. Accessed January, 2020 .

48. Peltzer K, Pengpid S. Prevalence, risk awareness and health beliefs of behavioural risk factors for cardiovascular disease among university students in nine ASEAN countries. BMC Public Health. 2018;18(1):237. doi:10.1186/s12889-018-5142-1

49. He FJ, Wu Y, Feng XX, et al. School based education programme to reduce salt intake in children and their families (School-EduSalt): cluster randomised controlled trial. BMJ. 2015;350:h770. doi:10.1136/bmj.h770

50. Global Action Plan for the Prevention and Control of Noncommunicable Diseases 2013-2020. 2013. Available from: https://apps.who.int/iris/bitstream/handle/10665/94384/ 9789241506236_eng.pdf?sequence=1. Accessed January, 2020.

51. Do HT, Santos JA, Trieu K, et al. Effectiveness of a Communication for Behavioral Impact (COMBI) intervention to reduce salt intake in a vietnamese province based on estimations from spot urine samples. J Clin Hypertens (Greenwich). 2016;18(11):1135-1142. doi:10.1111/jch.12884

52. Cummings KM. Programs and policies to discourage the use of tobacco products. Oncogene. 2002;21(48):7349-7364. doi:10.1038/sj.onc. 1205810

53. "Sin Tax" Expands Health Coverage in the Philippines. 2015. Available from: https://www.who.int/features/2015/ncdphilippines/en/. Accessed January, 2020

54. Austria MS, Pagaduan JA. Assessing the Impact of the Philippine Assessing the Impact of the Philippine Sin Tax Reform Law on the Demand for Cigarettes Sin Tax Reform Law on the Demand for Cigarettes Working Paper Series Working Paper Series er Series 2018-03-051. Manila, Philippines: De La Salle University; 2018

55. Salvador D Jr, Mo M, Sales K Higher alcohol taxes will improve population health and augment UHC funds. 2019. Available from https://www.bworldonline.com/higher-alcohol-taxes-will-improvepopulation-health-and-augment-uhc-funds/. Accessed January, 2020.

56. Department of Health. Sin Tax Law. Incremental Revenue for Health: Annual Report 2019. 2019; Available from: https://www. doh.gov.ph/sites/default/files/publications/SinTax\%202019\% 20Annual\%20Report.pdf. Accessed January, 2020.

57. Dayrit MM, Lagrada LP, Picazo OF, et al. The Philippines Health System Review. 2018. Available from: http://apps.searo.who.int/ PDS_DOCS/B5438.pdf. Accessed January, 2020.

58. Arena R, Guazzi M, Lianov L, et al. Healthy lifestyle interventions to combat noncommunicable disease-a novel nonhierarchical connectivity model for key stakeholders: a policy statement from the American Heart Association, European Society of Cardiology, European Association for Cardiovascular Prevention and Rehabilitation, and American College of Preventive Medicine. Eur Heart J. 2015;36(31):2097-2109. doi:10.1093/eurheartj/ehv207

59. The power of cities: Tackling noncommunciable dieases and road traffic injuries. 2019. Available from: https:/www.who.int/ncds publications/tackling-ncds-in-cities/en/. Accessed January, 2020.
60. Promoting healthy cities with healthy partners. 2017. Available from: https:/www.healthy-partners.net/2017/02/02/healthy-citiesthe-marikina-experience/. Accessed January, 2020.

61. Ng CH. Mental health and integration in Asia Pacific. BJPsych Int. 2018;15(4):76-79. doi:10.1192/bji.2017.28

62. Davidson KW. Depression and coronary heart disease. ISRN Cardiol. 2012;2012:743813. doi:10.5402/2012/743813

63. Psychiatrists and Nurses Working in Mental Health Sector (per 100,000 population), 2014-2016. 2019. Available from: http:// gamapserver.who.int/gho/interactive_charts/mental_health/psy chiatrists nurses/atlas.html. Accessed January, 2020.

64. Whooley MA, Avins AL, Miranda J, Browner WS. Case-finding instruments for depression. Two questions are as good as many. $J$ Gen Intern Med. 1997;12(7):439-445. doi:10.1046/j.15251497.1997.00076.x

65. Package of Essential Noncommunicable (PEN) Disease Interventions for Primary Health Care in Low-Resource Settings. 2010. Available from: https://www.who.int/nmh/publi cations/essential_ncd_interventions_lr_settings.pdf. Accessed January, 2020.

66. Ngo VK, Rubinstein A, Ganju V, et al. Grand challenges: integrating mental health care into the non-communicable disease agenda. PLoS Med. 2013;10(5):e1001443. doi:10.1371/journal. pmed.1001443

67. Kongsuk T, Supanya S, Kenbubpha K, Phimtra S, Sukhawaha S, Leejongpermpoon J. Services for depression and suicide in Thailand. WHO South East Asia J Public Health. 2017;6 (1):34-38. doi:10.4103/2224-3151.206162

68. Thawornchaisit P, de Looze F, Reid CM, Seubsman SA, Sleigh AC. Thai Cohort Study T. Health risk factors and the incidence of hypertension: 4-year prospective findings from a national cohort of 60569 Thai Open University students. BMJ Open. 2013;3(6):6. doi:10.1136/bmjopen-2013-002826

69. World Health Organization. Country Office for Thailand. Hypertension care in Thailand: best practices and challenges, 2019. 2019. Available from: https://apps.who.int/iris/handle/ 10665/330488. Accessed May, 2020.

70. Viswanathan M, Golin CE, Jones CD, et al. Closing the quality gap: revisiting the state of the science (vol. 4: medication adherence interventions: comparative effectiveness). Evid Rep Technol Assess (Full Rep). 2012;208(4):1-685.

71. FG Lin EH, Von Korff M, Katon W, et al. The role of the primary care physician in patients' adherence to antidepressant therapy. Med Care. 1995;33(1):67-74. doi:10.1097/00005650-19950100000006

72. Chong Guan N, Zaini S. Shared decision making in the treatment of depression. Malaysian J Psychiatry. 2018;27:2.

73. Lee YK, Ng CJ. The state of shared decision making in Malaysia. Z Evid Fortbild Qual Gesundhwes. 2017;123-124:66-68. doi:10.1016/j.zefq.2017.05.019

74. Zaini S, Manivanna Bharathy HA, Sulaiman $\mathrm{AH}$, et al. Development of a strategic tool for shared decision-making in the use of antidepressants among patients with major depressive disorder: a focus group study. Int J Environ Res Public Health. 2018;15:7. doi:10.3390/ijerph15071402

75. Elwyn G, Durand MA, Song J, et al. A three-talk model for shared decision making: multistage consultation process. $B M J$. 2017;359:j4891. doi:10.1136/bmj.j4891

76. Zwarenstein M, Goldman J, Reeves S. Interprofessional collaboration: effects of practice-based interventions on professional practice and healthcare outcomes. Cochrane Database Syst Rev. 2009;(3):CD000072.

77. Zimmerman J, Dabelko HI. Collaborative models of patient care: newopportunities for hospital social workers. Soc Work Health Care. 2007;44(4):33-47. doi:10.1300/J010v44n04_03 
78. Ko GT, So WY, Tong PC, et al. From design to implementationthe Joint Asia Diabetes Evaluation (JADE) program: a descriptive report of an electronic web-based diabetes management program. BMC Med Inform Decis Mak. 2010;10(1):26. doi:10.1186/14726947-10-26

79. Chan JCN Designing a sustainable public-private-partnership program to enhance diabetes care and evaluating its impact using an outcomes simulation model. 2017. Available from: https://www. pico.gov.hk/doc/en/research_report(PDF)/2015_A4_008_15C_ Final_Report_Prof_Chan.pdf. Accessed January, 2020.

80. Chan ${ }^{-}$, So $\bar{W}, K_{0}^{-}$G, et al. The Joint Asia Diabetes Evaluation (JADE) Program: a web-based program to translate evidence to clinical practice in Type 2 diabetes. Diabet Med. 2009;26 (7):693-699. doi:10.1111/j.1464-5491.2009.02751.x

81. Beating non-communicable diseases in the community: The contribution of pharmacists. International Pharmaceutical Federation (FIP). 2019. Available from: https://www.fip.org/files/content/pub lications/2019/beating-ncds-in-the-community-the-contributionof-pharmacists.pdf. Accessed January, 2020.

82. Ministry Of Health, Singapore. National Pharmacy Strategy Information Pack. 2019. Available from: https://www.moh.gov. sg/docs/librariesprovider4/default-document-library/nps-infopack_revised.pdf. Accessed January, 2020.

83. Liew I First pharmacists, advanced practice nurses certified to prescribe medicines. 2018; https:/www.straitstimes.com/singa pore/first-pharmacists-advanced-practice-nurses-now-certified-toprescribe-medicines. Available from: Accessed January, 2020.

84. Mental Health Atlas 2011. 2011. Available from: https://apps. who.int/iris/bitstream/handle/10665/44697/9799241564359_eng. pdf? sequence=1. Accessed January, 2020.

85. Integrating Mental Health Services into Primary Health Care. 2007. Available from: https://www.who.int/mental_health/policy/ services/3_MHintoPHC_Infosheet.pdf. Accessed January, 2020.

86. Lim CG, Loh H, Renjan V, Tan J, Fung D. Child community mental health services in Asia Pacific and Singapore's REACH model. Brain Sci. 2017;7(12):10. doi:10.3390/brainsci7100126

87. Lewis T, Synowiec C, Lagomarsino G, Schweitzer J. E-health in low- and middle-income countries: findings from the Center for Health Market Innovations. Bull World Health Organ. 2012;90 (5):332-340. doi:10.2471/BLT.11.099820

88. Patel A, Praveen D, Maharani A, et al. Association of multifaceted mobile technology-enabled primary care intervention with cardiovascular disease risk management in rural Indonesia. JAMA Cardiol. 2019;4(10):978-986. doi:10.1001/jamacardio. 2019.2974

89. Assessing National Capacity for the Prevention and Control of Noncommunicable Diseases: Report of the 2017 Global Survey. 2018. Available from: https://apps.who.int/iris/bitstream/handle/ 10665/276609/9789241514781-eng.pdf?ua=1. Accessed January, 2020.

90. Varghese C, Nongkynrih B, Onakpoya I, McCall M, Barkley S, Collins TE. Better health and wellbeing for billion more people: integrating non-communicable diseases in primary care. $B M J$. 2019;364:1327. doi:10.1136/bmj.1327

91. Glossary. World Health Organization. 2016. Available from: https://www.who.int/global-coordination-mechanism/dialogues/ glossary-whole-of-govt-multisectoral.pdf. Accessed January, 2020 .
92. Akeroyd JM, Chan WJ, Kamal AK, Palaniappan L, Virani SS. Adherence to cardiovascular medications in the South Asian population: a systematic review of current evidence and future directions. World J Cardiol. 2015;7(12):938-947. doi:10.4330/ wjc.v7.i12.938

93. Mahipala P, Dorji G, Tisocki K, Rani M. A critical review of addressing cardiovascular and other non-communicable diseases through a primary health care approach in the South-East Asia Region. Cardiovasc Diagn Ther. 2019;9(2):150-157. doi:10.21037/cdt.2018.09.03

94. Maharani A, Sujarwoto PD, Oceandy D, Tampubolon G, Patel A. Cardiovascular disease risk factor prevalence and estimated 10-year cardiovascular risk scores in Indonesia: the SMARThealth Extend study. PLoS One. 2019;14(4):e0215219. doi:10.1371/journal.pone.0215219

95. Bandar Seri Begawan Declaration on Noncommunicable Diseases in ASEAN. 2013. Available from: https://www.asean.org/wpcontent/uploads/images/archive/23rdASEANSummit/3.\%20bsb $\%$ 20declaration $\% 20$ on $\% 20$ ncd $\% 20$ in $\% 20$ asean- $\% 20$ final-endorsed \%2023\%20september\%202013.pdf. Accessed May, 2020.

96. ASEAN renews commitment for a healthier ASEAN. 2017. Available from: https://asean.org/asean-renews-commitment-healthier-asean/? highlight=non-communicable\%20diseases. Accessed May, 2020.

97. Van Bewer V. Transdisciplinarity in health care: a concept analysis. Nurs Forum. 2017;52(4):339-347. doi:10.1111/nuf.12 200

98. WHO gets new advice on curbing deadly noncommunicable diseases. 2019. Available from: https://www.who.int/news-room /detail/10-12-2019-who-gets-new-advice-on-curbing-deadlynoncommunicable-diseases. Accessed May, 2020.

99. Asean Countries 2020. 2020. Available from: http://worldpopula tionreview.com/countries/asean-countries/. Accessed May, 2020.

100. Peters DH, Peters MA, Wickramasinghe K, Osewe PL, Davidson PM. Asking the right question: implementation research to accelerate national non-communicable disease responses. BMJ. 2019;365:11868. doi:10.1136/bmj.11868

101. Allen L, Bloomfield A; Working Group of the Global Coordination Mechanism on N. Engaging the private sector to strengthen NCD prevention and control. Lancet Glob Health. 2016;4(12):e897-e898. doi:10.1016/S2214-109X(16)30216-9

102. WHO Guideline: Recommendations on Digital Interventions for Health System Strengthening 2019. Available from: https:/apps. who.int/iris/bitstream/handle/10665/311941/9789241550505-eng. pdf. Accessed January, 2020.

103. Magrabi F, Ammenwerth E, McNair JB, et al. Artificial intelligence in clinical decision support: challenges for evaluating AI and practical implications. Yearb Med Inform. 2019;28 (1):128-134. doi:10.1055/s-0039-1677903

104. The Nueva Ecija Cardiovascular Risk Experiment (NECVaRE). 2019. Available from: https://clinicaltrials.gov/ct2/show/ NCT03512691. Accessed January, 2020.

105. Palafox B, Seguin ML, McKee M, et al. Responsive and Equitable Health Systems-Partnership on Non-Communicable Diseases (RESPOND) study: a mixed-methods, longitudinal, observational study on treatment seeking for hypertension in Malaysia and the Philippines. BMJ Open. 2018;8(7):e024000. doi:10.1136/bmjopen-2018-024000 


\section{Publish your work in this journal}

Risk Management and Healthcare Policy is an international, peerreviewed, open access journal focusing on all aspects of public health, policy, and preventative measures to promote good health and improve morbidity and mortality in the population. The journal welcomes submitted papers covering original research, basic science, clinical \& epidemiological studies, reviews and evaluations,

guidelines, expert opinion and commentary, case reports and extended reports. The manuscript management system is completely online and includes a very quick and fair peer-review system, which is all easy to use. Visit http://www.dovepress.com/testimonials.php to read real quotes from published authors.

Submit your manuscript here: https://www.dovepress.com/risk-management-and-healthcare-policy-journal 